\title{
SURVEI TERHADAP TERJADINYA KEKERASAN DALAM RUMAH TANGGA (KDRT) WANITA KARIER DI DAERAH ISTIMEWA YOGYAKARTA
}

\author{
Das Salirawati, Antuni Wiyarsi dan Eddy Sulistyowati \\ FMIPA Universitas Negeri Yogyakarta \\ E-mail: das.salirawati@yahoo.co.id
}

\begin{abstract}
Abstrak: Survei Terhadap Terjadinya Kekerasan dalam Rumah Tangga (KDRT) Wanita Karier di Daerah Istimewa Yogyakarta. Penelitian ini bertujuan untuk mengetahui persentase wanita karier di wilayah DIY yang mengalami KDRT ditinjau dari keempat jenis KDRT yang ada dan persentase wanita karier di wilayah DIY yang mengalami KDRT ditinjau dari usia perkawinan. Penelitian ini didesain sebagai penelitian deskriptif dengan metode survei terhadap wanita karier yang ada di wilayah DIY. Variabel penelitian adalah KDRT pada wanita karier yang berprofesi sebagai pendidik (guru/dosen) dari lima Kabupaten yang ada di DIY. Populasi penelitian adalah seluruh pendidik (guru/ dosen) yang berasal dari lima Kabupaten di DIY, yaitu Kota, Bantul, Sleman, Kulon Progo, dan Gunung Kidul. Sampel penelitian sebanyak 40 wanita karier per Kabupaten yang diambil secara area purpossive sampling. Instrumen penelitian berupa angket yang dijabarkan berdasarkan keempat bentuk KDRT sesuai dengan UU Penghapusan KDRT No. 23 Tahun 2004, yaitu kekerasan fisik, psikis, seksual, dan ekonomi, sehingga memenuhi validitas logis. Hasil penelitian menunjukkan bahwa persentase wanita karier di wilayah DIY yang mengalami KDRT ditinjau dari kekerasan fisik, psikis, seksual, dan ekonomi berturut-turut sebesar 20,462\%, $21,415 \%, 21,127 \%$, dan 21,283\%. Secara keselu-ruhan persentase rata-rata untuk semua jenis KDRT sebesar $21,072 \%$ dengan kriteria/kategori rendah. Persentase wanita karier di wilayah DIY yang mengalami KDRT mulai dari usia perkawinan 1 - 5 tahun, 5,1 - 10 tahun, 10,1 - 15 tahun, dan > 15 tahun berturut-turut sebesar $21,544 \%, 20,828 \%, 21,435 \%$, dan 21,223\%, semua dalam kriteria/kategori rendah. Data menunjukkan bahwa terdapat sebagian kecil wanita karier yang berprofesi pendidik (guru/dosen) yang mengalami KDRT.
\end{abstract}

Kata kunci: kekerasan dalam rumah tangga, wanita karier, kekerasan pada wanita

\begin{abstract}
A Survey of The Occurrence of Domestic Violence to Career Women in DIY. This research aims to know the percentage of career womans in DIY who experienced violence in household. The violence saw from four gender of Violence in Household and ages of married. This research is designed in descriptive experimental with survey method. Variables of this research is violence in household for career womens as teahers or lecturer from five area in DIY. The population is the whole of career womens as teahers or lecturer from five area in DIY. The samples take with area purpossive sampling that is 40 career womans every area. Questionnaire as experimental instrument is maked based on the law of the Elimination of Violence in Household Act No. 23, 2004, so fill of logic validity. There is contain four gender of violence in household i.e physical, psychological, sexual and economic violence. Percentage of career womans in DIY that experience violence in household sew from physical, psychological, sexual and economic violence in succession are $20.462 \%, 21.415 \%, 21.127 \%$, and $21.283 \%$. Entirely, rate of percentage for all gender of violence in household is $21.072 \%$ that included in low criteria. The percentage of career womans in DIY that experience of violence in household for ages of married 1 - 5 years, 5.1- 10 years, $10.1-15$ years and $>15$ years in succession are $21.544 \%, 20.828 \%, 21.435 \%$, and $21.223 \%$. all the result is included in low criteria. This research is indicated that violence in household is experienced by few of career woman as teacher or lecturer.
\end{abstract}

Key words : Violence in Household, career woman, Violence at woman. 


\section{PENDAHULUAN}

Kehidupan rumah tangga yang damai, sejahtera, dan bahagia adalah dambaan setiap keluarga. Tidak ada satupun wanita di dunia ini yang menginginkan kehidupan rumah tangga yang kandas di tengah jalan, karena harus mengalami perceraian dalam rumah tangganya. Kekerasan Dalam Rumah Tangga (KDRT) telah menjadi agenda bersama dalam beberapa dekade terakhir. Fakta menunjukkan bahwa KDRT memberikan efek negatif yang cukup besar bagi wanita sebagai korban. World Health Organization (WHO) dalam World Report pertamanya mengenai "Kekerasan dan Kesehatan" di tahun 2002, menemukan bahwa antara 40$70 \%$ wanita yang meninggal karena pembunuhan, umumnya dilakukan oleh mantan atau pasangannya sendiri. Laporan Khusus dari PBB mengenai "Kekerasan terhadap Wanita" telah mendefinisikan KDRT dalam bingkai gender sebagai "kekerasan yang dilakukan di dalam lingkup rumah tangga dengan target utama terhadap wanita dikarenakan peranannya dalam lingkup tersebut; atau kekerasan yang dimaksudkan untuk memberikan akibat langsung dan negatif pada wanita dalam lingkup rumah tangga." Ada empat jenis kekerasan dalam rumah tangga, yaitu kekerasan fisik, psikis, seksual dan ekonomi. Namun demikian, masyarakat umum memahami kekerasan biasanya hanya sebatas pada kekerasan fisik.

Wanita karier adalah wanita yang bukan hanya bekerja di sektor domestik, tetapi juga di sektor publik. Perannya yang ganda tersebut seringkali memberikan kesibukan yang luar biasa, sehingga kadang-kadang intensitas komunikasi dengan pasangan hidupnya relatif kurang. Komunikasi yang kurang kemungkinan dapat menyebabkan masalah kecil dalam rumah tangga menjadi masalah yang besar jika tidak segera diatasi. Tidak jarang hal ini menimbulkan pertengkaran dan adu mulut, bahkan sampai menimbulkan kekerasan fisik bagi wanita. Akan tetapi, karena wanita karier sibuk dengan berbagai akitivitas, kadang-kadang keadaan rumah tangga yang dialaminya tidak terlalu dipikirkan, termasuk tidak pernah berpikir tentang adanya KDRT dalam rumah tangganya.

Berdasarkan hal tersebut, maka perlu kiranya dilakukan survei tentang terjadinya KDRT wanita karier agar mereka menyadari bahwa adanya KDRT sekecil apapun perlu dikomunikasikan dengan pasangannya, sehingga tidak menjadi pemicu masalah di kemudian hari yang dapat berakibat fatal pada terjadinya perceraian. Penelitian ini difokuskan pada responden yang berprofesi sebagai pendidik (guru/dosen) karena sebagai pendidik yang berperan menanamkan nilai-nilai karakter yang baik dan akhlak mulia kepada peserta didiknya umumnya sangat tertutup terhadap masalah pribadi yang dihadapinya. Artinya ketika ia mengajar semua permasalahan pribadi sedapat mungkin ditekan sedemikian rupa agar tidak terlihat di hadapan peserta didiknya. Keadaan ini berakibat sulitnya terdeteksi terjadi atau tidaknya dan mengalami atau tidaknya kekerasan dalam rumah tangga seorang pendidik.

\section{Profesi Pendidik}

Pendidik (guru/dosen) merupakan keterampilan profesional yang untuk menyandang profesi tersebut harus menempuh jenjang pendidikan tinggi pada program studi kependidikan (Mohamad Ali, 1984 : 31-34). Ada satu peristiwa di Amerika Serikat yang ada kaitannya dengan profesi pendidik, yaitu pada tahun 1948. Ketika itu banyak pasien masuk ke rumah sakit besar di Amerika Serikat, ternyata yang menderita gangguan mental $17 \%$ pasien dokter, $19 \%$ petani, $30 \%$ dokter gigi, 36\% ahli hukum dan ibu rumahtangga, dan $55 \%$ pendidik (Nasution, 1982; 121). Hal ini kemungkinan besar disebabkan pekerjaan sebagai pendidik seringkali menimbulkan ketegangan dan frustasi. Keadaan ini sangat dimungkinkan menimpa pendidik wanita, karena selain harus menjalankan tugas sebagai pendidik yang demikian berat, juga masih terbebani pekerjaan domestikyang juga berat. Terlebih jika pasangannya tidak mau tahu dan tidak 
meringankan beban pekerjaan tersebut. Secara psikologis, keadaan ini berpengaruh pada ketidakberdayaan wanita, menarik diri dari lingkungan, dan penurunan motivasi (Kendall \& Hammen, 1984).

Peran ganda wanita karier menyebabkan mereka harus pandai-pandai membagi waktu dan tenaga dengan sebaik-baiknya, namun demikian seringkali pekerjaan domestik menjadi terbengkalai. Bagi pasangannya yang dapat memahami dan memaklumi mungkin keadaan ini tidak menjadi masalah, tetapi sebagian dari mereka menganggap suatu masalah, sehingga tidak jarang berujung pada pertengkaran kecil menjadi besar sampai pada kekerasan fisik. Perasaan wanita yang mudah tersinggung, menyebabkan setiap kali terjadi pertengkaran meninggalkan luka hati yang disimpan sangat dalam dan suatu saat akan dapat meledak menjadi pertengkaran hebat (Kartini Kartono, 1977: 190).

Oleh karena wanita karier dalam kehidupan kesehariannya disibukkan oleh berbagai aktivitas publik dan domestik, sehingga jarang mereka merenungkan bahwa apa yang dialami dalam rumah tangganya merupakan bentuk KDRT. Sosialisasi isi UU Penghapusan KDRT kepada khalayak masyarakat diharapkan dapat menjadi pengendali jika seseorang akan melakukan KDRT.

\section{Wanita Karier}

Wanita karier adalah mereka yang memiliki kemampuan yang tinggi dalam mengorganisasikan pekerjaan mereka, sehingga dapat mencapai prestasi, tetapi tetap dapat menjalankan fungsinya sebagai ibu rumah tangga (Juwairiyah Dahlan, 1999). Pada umumnya wanita karier memiliki masalah intern, seperti terbatasnya waktu dan kesempatan mendidik anak, tugas rumah tangga yang terbengkalai, lemahnya kondisi fisik akibat kerja di kantor. Sedangkan masalah ekstern yang dihadapi antara lain kurangnya pengertian suami terhadap keadaan istri, sulitnya berperan ganda karena sebagian besar suami menyerahkan pekerjaan rumah tangga dan pendidikan anak kepada istri, faktor pandangan lingkungan yang kadangkadang tidak mengenakkan hati.

Penelitian yang dilakukan Susilaningsih (1996: 106) terhadap wanita karier di Kabupaten Gunung Kidul menunjukkan meningkatnya gugat cerai yang sebagian beralasan karena adanya KDRT yang sudah lama mereka alami dan setelah tidak kuat baru mengajukan gugat cerai. Namun mereka tidak mengetahui bahwa alasan tersebut termasuk KDRT dan ada UU yang melindunginya

\section{UU Penghapusan Kekerasan dalam Ru- mah Tangga (KDRT)}

Berdasarkan hasil Rapat Paripurna Dewan Perwakilan Rakyat pada tanggal 14 September 2004, telah disahkan UndangUndang No. 23 tahun 2004 mengenai Penghapusan Kekerasan Dalam Rumah Tangga (PKDRT) yang terdiri dari 10 bab dan 56 pasal, yang diharapkan dapat menjadi payung perlindungan hukum bagi anggota dalam rumah tangga, khususnya wanita, dari segala tindak kekerasan.

Secara garis besar UU ini berisi tentang ketentuan umum, meliputi pengertian KDRT, penghapusan KDRT, korban KDRT, perlindungan, perintah perlindungan, dan lingkup rumah tangga. Bab-bab selanjutnya mengatur tentang asas dan tujuan diadakannya penghapusan KDRT, larangan KDRT termasuk bentuk-bentuk KDRT, hakhak korban, kewajiban Pemerintah dan masyarakat, perlindungan, pemulihan korban, dan ketentuan pidana. Pada umumnya orang awam menganggap bahwa perbuatan yang termasuk KDRT hanyalah sebatas kekerasan fisik, padahal menurut UU Penghapusan KDRT No. 23/2004 Pasal 5 - 9, bentuk-bentuk kekerasan yang dimaksud dapat berupa kekerasan fisik, psikis, seksual dan ekonomi.

Menurut UU Penghapusan KDRT, KDRT adalah setiap perbuatan terhadap seseorang terutama perempuan, yang berakibat timbulnya kesengsaraan atau penderitaan secara fisik, seksual, psiologis, dan/atau penelantaran rumah tangga termasuk ancaman 
untuk melakukan perbuatan, pemaksaan, atau perampasan kemerdekaan secara melawan hukum dalam lingkup rumah tangga. Adapun penghapusan KDRT adalah jaminan yang diberikan oleh negara untuk mencegah terjadinya KDRT, menindak pelaku KDRT, dan melindungi korban KDRT.

Pada tingkat internasional, kekerasan terhadap wanita telah dilihat sebagai suatu bingkai kejahatan terhadap hak dan kebebasan dasar wanita serta perusakan dan pencabutan kebebasan mereka terhadap hak-hak yang melekat pada dirinya. Hal ini menjadi sebuah tantangan dalam pencapaian persamaan hak, pengembangan dan kedamaian yang diakui dalam Nairobi Forward-looking Strategis for the Advancement of Women, yang merekomendasikan satu perangkat tindakan untuk memerangi kekerasan terhadap wanita. Rekomendasi tersebut dibebankan kepada Pemerintah sebagai kewajiban hukum dan moral untuk menghilangkan KDRT melalui kombinasi berbagai langkah serius.

KDRT merupakan permasalahan yang telah mengakar sangat dalam dan terjadi di seluruh negara dunia. Oleh karena itu masyarakat internasional telah menciptakan standar hukum yang efektif dan khusus memberikan perhatian terhadap KDRT. Sebagai contoh, tindakan memukul wanita telah dimasukkan di dalam konvensi HAM internasional maupun regional yang mempunyai sifat hukum mengikat terhadap negara yang telah meratifikasinya. Dokumen HAM Internasional tersebut, meliputi Universal Declaration of Human Rights (UDHR), the International Covenant on Civil and Political Rights (ICCPR), dan the International Covenant on Economic, Social and Cultural Rights (ICESCR) yang menjadi standar umum mengenai Hak Asasi Manusia, dimana para korban dari KDRT dapat menggugat negaranya masing-masing.

\section{METODE}

Penelitian ini didesain sebagai penelitian deskriptif dengan metode survei terhadap wanita karier yang berprofesi sebagai tenaga pendidik (guru/dosen) yang ada di wilayah DIY. Variabel penelitian adalah KDRT pada wanita karier yang berprofesi sebagai pendidik (guru/dosen) dari lima Kabupaten yang ada di DIY. Populasi penelitian adalah seluruh pendidik (guru/dosen) yang berasal dari lima Kabupaten di DIY, yaitu Kota, Bantul, Sleman, Kulon Progo, dan Gunung Kidul. Sampel dalam penelitian ini sebanyak 40 wanita pendidik (guru/dosen) per Kabupaten, yang diambil secara area purpossive sampling.

Instrumen penelitian berupa angket yang dijabarkan berdasarkan keempat bentuk KDRT sesuai dengan UU Penghapusan KDRT No. 23 Tahun 2004, yaitu kekerasan fisik, psikis, seksual, dan ekonomi, sehingga memenuhi validitas logis. Setiap butir angket mengandung lima alternatif jawaban, yaitu tidak pernah (TP), jarang (J), kadang-kadang $(\mathrm{K})$, sering $(\mathrm{S})$, dan sangat sering (SS). Pemberian skor jawaban berturut-turut adalah $1,2,3,4$, dan 5 . Data berupa skor terjadinya KDRT dari masing-masing pendidik (guru/ dosen) yang menjadi sampel yang kemudian dijumlahkan sesuai dengan bentuk KDRT yang ada dan diubah menjadi bentuk persentase. Selanjutnya skor terjadinya KDRT dipisahkan sesuai dengan bentuk kekerasan dan interval usia perkawinan yang ditetapkan dalam penelitian ini. Terakhir, persentase yang diperoleh dikonversi ke dalam kriteria kualitatif dengan kategori sangat tinggi, tinggi, sedang, rendah dan sangat rendah.

\section{HASIL DAN PEMBAHASAN Hasil Penelitian}

Berdasarkan data yang diperoleh dari pengisian angket identifikasi terjadi-nya Kekerasan dalam Rumah Tangga (KDRT), diperoleh data awal berupa jawaban tiga pertanyaan sederhana untuk menjajagi tentang pernah/tidaknya responden mendengar dan tahu/tidaknya responden tentang KDRTdiperoleh rekapitulasi jawaban pada Tabel 1. Adapun tiga jawaban tertinggi atas pertanyaan ketiga yang berupa penjelasan singkat responden tentang KDRT disajikan 
pada Tabel 2.

Berdasarkan data yang diperoleh dari pengisian angket, maka diperoleh skor ratarata setiap jenis atau bentuk KDRT yang dialami wanita karier setiap kabupaten yang ada di wilayah DIY, khususnya pendidik (guru/dosen). Hasil perhitungan disajikan pada Tabel 3.

Sesuai dengan tujuan penelitian ini, maka selanjutnya dihitung persentase ratarata setiap bentuk/jenis KDRT ditinjau dari usia perkawinan untuk setiap kabupaten yang ada di wilayah DIY. Adapun hasilnya disajikan pada Tabel 4.

\section{Pembahasan}

Penelitian ini bertujuan untuk mengetahui persentase wanita karier di wilayah DIY yang mengalami KDRT ditinjau dari keempat jenis KDRT yang ada dan persentase wanita karier di wilayah DIY yang mengalami KDRT ditinjau dari usia perkawinan. Adapun wanita karier yang dimaksud dibatasi pada wanita karier yang berprofesi pendidik (guru/dosen).

Berdasarkan pengolahan data dari angket yang diisi responden dari lima Kabupaten, maka diperoleh rerata KDRT dari keempat jenis KDRT untuk setiap Kabupaten

Tabel 1. Rekapitulasi Penjajagan Pengetahuan tentang KDRT Responden

\begin{tabular}{llll}
\hline Pertanyaan & \multicolumn{3}{c}{ Jawaban } \\
\cline { 2 - 3 } & Tidak Pernah & \multicolumn{1}{c}{ Pernah } \\
\hline Apakah Ibu pernah mendengar & $1(0,5 \%)$ & $199(99,5 \%)$ \\
tentang KDRT? & Tidak Tahu & Sedikit Tahu & Tahu \\
Apakah Ibu tahu apa itu KDRT? & $2(1 \%)$ & $83(41,5 \%)$ & $115(57,5 \%)$ \\
\hline
\end{tabular}

Tabel 2. Beberapa Penjelasan Singkat tentang KDRT oleh Responden

\begin{tabular}{llcc}
\hline No & \multicolumn{1}{c}{ Jawaban } & Jumlah & \% \\
\hline 1. & $\begin{array}{l}\text { Kekerasan yang terjadi dalam rumah tangga, baik fisik, psikis, } \\
\text { seksual maupun ekonomi. }\end{array}$ & 68 & 34 \\
2. & $\begin{array}{l}\text { Kekerasan yang dilakukan oleh anggota keluarga yang satu } \\
\text { terhadap yang lain (suami terhadap istri, istri terhadap suami } \\
\text { atau orangtua terhadap anak) baik secara fisik maupun psikis. }\end{array}$ & 39,5 \\
3. $\begin{array}{l}\text { Kekerasan dalam rumah tangga yang dilakukan oleh suami } \\
\text { kepada istri yang berupa kekerasan fisik, psikis, seksual, dan } \\
\text { ekonomi. }\end{array}$ & 26 & 13 \\
\hline
\end{tabular}

Tabel 3. Persentase Rata-rata Setiap Jenis KDRT Setiap Kabupaten

\begin{tabular}{|c|c|c|c|c|c|c|c|}
\hline \multirow[t]{2}{*}{ No. } & \multirow{2}{*}{$\begin{array}{l}\text { Jenis } \\
\text { KDRT }\end{array}$} & \multicolumn{5}{|c|}{ Kabupaten (\%) } & \multirow[t]{2}{*}{ \% Rata- rata } \\
\hline & & Kota & Sleman & Bantul & GK & KP & \\
\hline 1. & $\begin{array}{l}\text { Kekerasan } \\
\text { Fisik }\end{array}$ & 20,125 & 20,375 & 20,156 & 21 & 20,656 & 20,462 \\
\hline 2. & $\begin{array}{l}\text { Kekerasan } \\
\text { Psikis }\end{array}$ & 20,423 & 22,154 & 20,423 & 21,462 & 22,615 & 21,415 \\
\hline 3. & $\begin{array}{l}\text { Kekerasan } \\
\text { Seksual }\end{array}$ & 20,867 & 21,5 & 21 & 20,767 & 21,5 & 21,127 \\
\hline 4. & $\begin{array}{l}\text { Kekerasan } \\
\text { Ekonomi }\end{array}$ & 20,167 & 21,667 & 20,333 & 22,333 & 21,917 & 21,283 \\
\hline \multicolumn{2}{|c|}{$\%$ Rerata } & $\begin{array}{l}20,396 \\
\text { (rendah) }\end{array}$ & $\begin{array}{l}21,424 \\
\text { (rendah) }\end{array}$ & $\begin{array}{l}20,478 \\
\text { (rendah) }\end{array}$ & $\begin{array}{l}21,391 \\
\text { (rendah) }\end{array}$ & $\begin{array}{l}21,672 \\
\text { (rendah) }\end{array}$ & $\begin{array}{l}21,072 \\
\text { (rendah) }\end{array}$ \\
\hline
\end{tabular}


Tabel 4. Skor Rata-rata Setiap Jenis KDRT Ditinjau dari Usia Perkawinan

\begin{tabular}{|c|c|c|c|c|c|c|c|c|}
\hline \multirow[t]{2}{*}{ No. } & \multirow{2}{*}{$\begin{array}{l}\text { UP } \\
\text { (Thn) }\end{array}$} & \multirow[t]{2}{*}{ Jenis KDRT } & \multicolumn{5}{|c|}{ Kabupaten (\%) } & \multirow{2}{*}{$\begin{array}{c}\% \\
\text { Rerata }\end{array}$} \\
\hline & & & Kota & Sleman & Bantul & GK & KP & \\
\hline \multirow[t]{5}{*}{1.} & $1-5$ & Kekerasan Fisik & 20 & 20,313 & 20 & 25,313 & 20,36 & 21,197 \\
\hline & & Kekerasan Psikis & 20 & 20,385 & 20,80 & 28,077 & 22,198 & 22,292 \\
\hline & & Kekerasan & 20,4 & 20,667 & 20,242 & 21,667 & 22,476 & 21,090 \\
\hline & & Seksual & & & & & & \\
\hline & & $\begin{array}{l}\text { Kekerasan } \\
\text { Ekonomi }\end{array}$ & 20 & 20 & 20 & 27,5 & 20,476 & 21,595 \\
\hline \multicolumn{3}{|c|}{$\%$ Rata-rata } & 20,1 & 20,341 & 20,261 & 25,639 & 21,378 & $\begin{array}{l}21,544 \\
\text { (rendah) }\end{array}$ \\
\hline \multirow[t]{5}{*}{2.} & $5,1-$ & Kekerasan Fisik & 20 & 20,268 & 20,556 & 20,329 & 20 & 20,231 \\
\hline & 10 & Kekerasan Psikis & 20 & 21,978 & 20,855 & 20,567 & 20,355 & 20,751 \\
\hline & & $\begin{array}{l}\text { Kekerasan } \\
\text { Seksual }\end{array}$ & 24 & 21,238 & 21,926 & 20,211 & 20,513 & 21,578 \\
\hline & & $\begin{array}{l}\text { Kekerasan } \\
\text { Ekonomi }\end{array}$ & 20 & 20,952 & 20 & 22,807 & 20 & 20,752 \\
\hline & \% Rata & rata & 21 & 21,109 & 20,834 & 20,979 & 20,217 & $\begin{array}{l}20,828 \\
\text { (rendah) }\end{array}$ \\
\hline \multirow[t]{4}{*}{3.} & $10,1-$ & Kekerasan Fisik & 20 & 20,357 & 20,179 & 22,083 & 21,25 & 20,774 \\
\hline & 15 & Kekerasan Psikis & 20,439 & 23,736 & 20 & 22,564 & 25,128 & 22,373 \\
\hline & & $\begin{array}{l}\text { Kekerasan } \\
\text { Seksual }\end{array}$ & 20,476 & 22,667 & 20,571 & 20 & 23,259 & 21,395 \\
\hline & & $\begin{array}{l}\text { Kekerasan } \\
\text { Ekonomi }\end{array}$ & 20,476 & 21,429 & 20 & 20 & 24,074 & 21,196 \\
\hline \multicolumn{3}{|c|}{ \% Rata-rata } & 20,348 & 22,047 & 20,1875 & 21,162 & 23,428 & $\begin{array}{l}21,435 \\
\text { (rendah) }\end{array}$ \\
\hline \multirow[t]{4}{*}{4.} & $>15$ & Kekerasan Fisik & 20,417 & 20,536 & 20 & 21,333 & 21,136 & 20,684 \\
\hline & & Kekerasan Psikis & 21,196 & 22,198 & 20,362 & 20 & 23,217 & 21,395 \\
\hline & & $\begin{array}{l}\text { Kekerasan } \\
\text { Seksual }\end{array}$ & 20,444 & 21,524 & 20,941 & 20,933 & 22,424 & 21,253 \\
\hline & & $\begin{array}{l}\text { Kekerasan } \\
\text { Ekonomi }\end{array}$ & 20,37 & 23,095 & 20 & 21 & 23,333 & 21,559 \\
\hline \multicolumn{3}{|c|}{$\%$ Rata-rata } & 21,838 & 21,838 & 20,326 & 20,817 & 22,528 & $\begin{array}{l}21,223 \\
\text { (rendah) }\end{array}$ \\
\hline
\end{tabular}

tersebut. Meskipun semua berada dalam kategori/kriteria rendah, tetapi sebenarnya jika dilihat dari pola jawaban ada beberapa responden yang mengalami KDRT, baik dalam bentuk kekerasan fisik, psikis, seksual, maupun ekonomi. Jika ditelusuri lebih lanjut, terbanyak responden mengalami kekerasan psikis $(21,415 \%)$. Hal ini sesuai kenyataan dalam kehidupan seorang wanita karier yang sibuk dengan berbagai akitivitas, kadang-kadang keadaan rumah tangga yang dialaminya tidak terlalu dipikirkan, termasuk tidak pernah berpikir bahwa ia telah mengalami kekerasan psikis dalam rumah tangganya.

Berdasarkan penelusuran butir-butir pernyataan yang termasuk dalam kekerasan psikis, maka butir nomor 21 yang berbunyi "diperlakukan yang dapat membuat susah tidur, stres dan depresi" menempati urutan pertama, yaitu sebesar 23\%. Kekerasan psikis yang demikian sering dialami wanita karier, mengingat masih banyaknya suami yang tidak dapat menerima seutuhnya jika istri sibuk bekerja. Akibatnya perselisihan paham sering terjadi karena kurangnya 
intensitas komunikasi suami istri. Jika perselisihan tidak segera dicarikan solusi, maka masalah ini akan terbawa terus hingga menyebabkan seorang istri menjadi sulit tidur. Keadaan ini jika dibiarkan dapat berakibat pada stres, dan akibat yang lebih fatal terjadinya depresi yang dapat membahayakan kehidupan rumah tangga.

Ditinjau dari skor total setiap butir, maka butir nomor 34 menempati urutan pertama. Butir tersebutberbunyi "memaksa hubungan seksual, meskipun ibu sedang tidak dapat melakukannya, karena sakit, kecapekan atau alasan logis lainnya". Hal ini dapat dipahami, bahwa kebutuhan seksual seorang wanita yang sudah berumah tangga terlebih sudah memiliki anak menjadi menurun seiring dengan pertambahan usia dan banyaknya aktivitas. Menurut Hembing Wijayakusuma (1999: 65-77), penyebab seorang istri menolak diajak melakukan hubungan seksual dengan suami terutama disebabkan faktor kelelahan dan kekhawatiran akan hamil lagi. Lebih lanjut dikemukakan dari hasil penelitian di Inggris terhadap 100 pasangan yang terdidik, ternyata terdapat $23 \%$ pasangan melakukan hubungan seksual 2-3 kali sebulan, 24\% sekali seminggu, dan $31 \%$ sebanyak 2-3 kali seminggu. Menurut penelitian tersebut, intensitas melakukan hubungan seksual menurun karena kesibukan mereka bekerja.

Dengan melihat kembali Tabel 3 yang telah disajikan sebelumnya menun-jukkan kabupaten yang respondennya terbesar mengalami semua jenis KDRT adalah Kabupaten Kulon Progo (21,672\%). Seperti diketahui, Kulon Progo merupakan wilayah luas yang jarang terjamah oleh aktivitas ceramah, sosialisasi dan sejenisnya dari orga-nisasi wanita di tingkat pusat maupun Provinsi. Hal ini sesuai dengan yang disam-paikan beberapa responden dari Kulon Progo yang sempat diwawancarai peneliti.

Berdasarkan Tabel 4 menunjukkan bahwa ditinjau dari usia perkawinan persentase rata-rata terbesar responden yang mengalami KDRT adalah mereka yang berada pada usia perkawinan 1 - 5 tahun $(22,292 \%)$.
Hal ini dapat dipahami karena di usia awal perkawinan biasanya suami istri sedang dalam masa saling mencari kesesuaian dan beradaptasi satu dengan yang lain, sehingga perselisihan paham dan pertengkaran kecil sangat mungkin terjadi. Bahkan di masa awal perkawinan biasanya sifat asli suami istri akan muncul, sehingga banyak kekerasan psikis terjadi, seperti tindakan dan atau ucapan yang merendahkan atau menghina; diperlakukan yang dapat membuat stres atau hilang percaya diri.

Kekerasan terbanyak yang dialami wanita pada usia perkawinan 1-5 tahun terdapat pada butir nomor 34, yaitu sebesar $23,2 \%$. Butir tersebut merupakan bagian dari kekerasan seksual yang bunyinya "memaksa hubungan seksual, meskipun ibu sedang tidak dapat melakukannya, karena sakit, kecapekan atau alasan logis lainnya". Pada umumnya, wanita yang memasuki usia awal perkawinan memiliki ketegangan sebelum melakukan hubungan seksual karena belum terbiasa dan belum menyadari bahwa melakukan hubungan seksual adalah suatu kewajiban dan keharusan untuk melanggengkan perkawinan mereka. Akibatnya ketika kelelahan, dengan mudahnya mereka menolak ajakan suami. Jika hal ini dibiarkan terus-menerus, maka keharmonisan rumah tangga dapat terganggu (Hembing Wijayakusuma, 1999: 65).

Pada usia perkawinan 5,1 - 10 tahun, KDRT terbanyak yang dialami adalah jenis kekerasan seksual, yaitu sebesar 21,578\%. Hal ini karena di tahun perkawinan ini biasanya wanita mulai menurun kebutuhan biologisnya, apalagi jika sudah memiliki anak, sensitivitas tubuh menjadi menurun perlahan-lahan.

Butir terbanyak kekerasan seksual pada usia 5,1 -10 tahun terdapat pada butir nomor 30, yaitu sebesar 24,7\%. Butir tersebut menyatakan adanya kekerasan seksual berupa "mencium secara paksa". Oleh karena definisi lebih lanjut tentang maksud mencium secara paksa tersebut tidak ada dalam UU Penghapusan KDRT, maka jumlah responden yang menjawab sering lebih ban- 
yak. Pada umumnya ketika usia perkawinan menginjak lima tahun kedua, perhatian istri terhadap suami tidak seperti awal-awal perkawinan, sehingga kemesraan kadang dilupakan. Ciuman adalah salah satu cara suami untuk menghibur istri karena ciuman diartikan sebagai luapan rasa cinta ia kepada istri.Namun kadang-kadang maksud baik suami tidak dapat diterima sama baiknya oleh istri, dan ini memnculkan pendapat seolah-olah ada pemaksaan mencium oleh sang istri.

Pada usia perkawinan 10,1 - 15 tahun, KDRT terbanyak yang dialami adalah jenis kekerasan psikis, yaitu sebesar 22,373\%. Hal ini karena di tahun perkawinan yang menginjak tahap lima tahun ketiga banyak ketegangan keluarga terjadi akibat penuh dengan masalah-masalah yang berkaitan dengan mendidik dan membesarkan anak yang kadang-kadang tidak sejalan, terutama banyak ucapan keras dan kasar kedua belah pihak (suami istri) dalam penyelesaian masalah. Apalagi jika suami istri tidak mampu menyiasati hidup, maka pada usia perkawainan ini sangat rawan terjadi percecokan dalam rumah tangga.

Butir terbanyak kekerasan psikis pada usia perkawinan 10,1 - 15 tahun terdapat pada butir nomor 21, yaitu sebesar $25,6 \%$ yang berbunyi "diperlakukan yang membuat susah tidur, stres dan depresi". Usia perkawinan pada masa transisi sering menimbulkan permasalahan dalam rumah tangga, mulai dari masalah dapur sampai pada masalah anak. Semua itu dapat memicu terjadinya kesalahpahaman antara suami istri, dan jika masalah tidak segera diselesaikan akan berdampak kurang baik bagi keharmonisan keluarga.

Pada usia perkawinan di atas 15 tahun, KDRT terbanyak yang dialami adalah jenis kekerasan ekonomi, yaitu sebesar 21,559\%. Seperti diketahui di usia perkawinan ini banyak kebutuhan keluarga yang harus dipenuhi, sehingga kehidupan semakin terasa berat, karena anak-anak mulai bersekolah, bahkan mungkin sudah ada yang kuliah. Jenis kekerasan yang terbanyak adalah yang berkaitan dengan pemenuhan kebutuhan ekonomi keluarga. Jenis kekerasan ekonomi yang terbanyak terdapat pada butir nomor 50 , yaitu sebesar $24,6 \%$ yang berbunyi "tidak memenuhi kebutuhan dasar ibu dan keluarga". Bahkan pada butir ini ditemukan adanya skor yang relatif tinggi jika dibandingkan skor yang lain, yaitu terjadi di Sleman sebesar 31,4\%. Ekonomi keluarga yang paspasan menyebabkan suami istri kesulitan dalam mencari tambahan pen-dapatan, sehingga pemenuhan kebutuhan dasar ibu dan keluarga sulit terpenuhi.

Penelitian ini telah berhasil menunjukkan bahwa ada sebagian kecil wanita karier yang berprofesi pendidik (guru/dosen) yang mengalami KDRT. Makna yang lebih mendalam dari hasil penelitian ini adalah perlunya dilakukan penelitian lanjutan terhadap wanita karier yang mengalami perceraian akibat gugat cerai dari pihaknya sendiri, agar benar-benar diperoleh informasi penting yang dapat menjadi bahan renungan sekaligus dapat dirancang kegiatan yang mampu membantu wanita-wanita yang mengalami masalah KDRT, sehingga angka perceraian dapat dikurangi perlahan-lahan.

\section{SIMPULAN}

Persentase wanita karier di wilayah DIY yang mengalami KDRT ditinjau dari kekerasan fisik, psikis, seksual, dan ekonomi berturut-turut sebesar 20,462\%, 21,415\%, $21,127 \%$, dan $21,283 \%$. Secara keseluruhan persentase rata-rata untuk semua jenis KDRT sebesar 21,072\% dengan kriteria/ kategori rendah. Persentase wanita karier di wilayah DIY yang mengalami KDRT mulai dari usia perkawinan 1 - 5 tahun, 5,1 - 10 tahun, 10,1 - 15 tahun, dan > 15 tahun berturut-turut sebesar 21,544\%, 20,828\%, $21,435 \%$, dan $21,223 \%$, semua dalam kriteria/kategori rendah.

\section{DAFTAR PUSTAKA}

Ebel, Robert L. (1972). Essentials of Educational Measurement. New Jersey : Prentice Hall Inc. Englewood Clift. 
Hembing Wijayakusuma. (1999). Frigiditas: Penyebab, Pencegah, dan Penyembuhannya. Jakarta: Handal Niaga Pustaka. Juwairiyah Dahlan. (1999). Peranan Wanita dalam Islam (Studi tentang Wanita Karier dan Pendidikan Anak. Disertasi. Yogyakarta: PPS IAIN Suka

Kartini Kartono. (1977). Psikologi Wanita. Bandung: Alumni.

Kedaulatan Rakyat. (2009). Selama 2009, Kasus KDRT Peringkat Teratas. Rabu, 6 Januari 2010

Kendall, P. C \& Hammen, C. (1984). Abnormal Psychology Understanding Human Problems. Boston: Houghton Mifflin Company.
Mohamad Ali. (1984). Pengembangan Kurikulum di Sekolah. Bandung : Sinar Baru. Nasution, S. (1987). Berbagai Pendekatan dalam Proses Belajar dan Mengajar. Jakarta : Bina Aksara.

Susilaningsih. (1997). Dinamika Kelompok Keagamaan sebagai Pendorong Usaha Peningkatan Kesejahteraan Ekonomi Keluarga. Yogyakarta : Fak. Tarbiyah IAIN Suka.

Undang-Undang Republik Indonesia Nomor 23 Tahun 2004 tentang Penghapusan Kekerasan Dalam Rumah Tangga. 